\title{
大学研究棟における加速度センサーを用いた 即時耐震性能評価法の実証実験
}

\author{
日比野陽 ${ }^{* 1} \cdot$ 楠 浩一 ${ }^{* 2} \cdot$ 勅使川原正臣*3 $\cdot$ 荒木正之*4
}

\begin{abstract}
概 要 近年, 建物の耐震性能を評価する方法として, 構造物のヘルスモニタリング技術が注目されている。本稿では, 広島大学工学部の鉄骨鉄筋コンクリート造建物に扔いて実施した, 加速度センサーを用いた即時耐震性能評価法の実証実 験について紹介している。加速度センサーにより計測された地震時の建物の加速度履歴を元にして, 建物の性能曲線を算 出し, 基礎への入力加速度および近隣の強震観測点で得られた加速度記録から求めた要求曲線と比較し, 耐震性能評価法 の検証を行った。伝達関数および性能曲線の骨格曲線から得られた固有周期の比較や性能曲線と要求曲線との関係図から 評価法の妥当性を示した。
\end{abstract}

キーワード : 加速度センサー, 即時耐震性能評価, 性能曲線, 要求曲線, 固有周期, 伝達関数

\section{1.はじめに}

近年, 建物の維持管理の重要性や性能の明示化が求め られるにつれ, 建築構造物の耐震性能や残余耐震性能の 把握が期待されている。建物の構造性能が把握できれば 住民にもわかりやすく説明することが可能になる。一方 で, 建物の構造性能を把握する方法として, 微動計測に よる固有周期の推定などが行われてきた。しかしながら, 固有周期のみの推定では建物の現状が把握できるもの の, 耐力や限界時の変形性能といった建物の限界性能ま での余力を把握することは困難であり，耐震性能を十分 に明らかにできているとは言い難い。また，近年の研究 において構造物ヘルスモニタリング (SHM : Structural Health Monitoring) の開発が行われている。例えば, センサーを使って部材の損傷を把握するもの ${ }^{1)}$ や，加速 度応答から建物に生ずる変位を推定するもの ${ }^{2)}$ などがあ る。しかしながら，損傷を把握する場合においては損傷 の程度を区別するための指標を定義する必要があり，そ の定義によっては，損傷の識別にバラつきが生じる。し たがって，損傷を判別するよりも，変位などの情報に加 えて, 強度や剛性を定量的に評価できるほうが耐震性能 の明示化に役立つ可能性がある。変位や強度, 剛性がわ かれば, 設計強度との比較が可能となり, 結果的に損傷 の程度の定量的な評価につながる。さらに, 保有水平耐 力や限界変形が推定できれば, 建物の残余耐震性能が評 価できると考えられる。一方，これらのモニタリング技 術を設計や耐震診断において使用することについてのガ イドラインはまだ整備されていないのが現状である。今

\footnotetext{
*1 ひびの・よう/広島大学大学院工学研究院 准教授 (正会員)

*2 くすのき・こういち/東京大学地震研究所 准教授 (正会員)

*3てしがわら・まさおみ/名古屋大学大学院環境学研究科 教授 (正 会員）

*4 あらき・まさゆき/(株)aLab 代表取締役社長
}

後，さらに多くの知見が蓄積され，ヘルスモニタリング技 術を用いた性能評価法が確立されれば，建物の耐震性能 を把握するための有効なツールになり得ると考えられる。

楠ら ${ }^{3), 4)}$ は加速度センサーを用いた建物の即時耐震性 能評価法について提案を行っており, 地震後の建物の耐 震性能を瞬時に評価することで, 余震に対する建物の安 全性評価法の確立を目指している。

筆者らは, この技術を実際の建物に実装し, 加速度セ ンサーを用いた構造物の即時耐震性能評価法の開発と実 証実験を行っている。実装した建物は筆者の所属する広 島大学の建物である。本稿では, 即時耐震性能評価法の 実装の概要とこれまでに計測された地震動により実施し た実証実験について紹介する。

\section{2. 即時耐震性能評価法の概要}

即時耐震性能評価法 ${ }^{3)}{ }^{4)}$ は Capacity Spectrum Method ${ }^{5}$ および限界耐力計算法を利用して，地震時に建物に生じ る加速度と変位から, 被災後の建物の耐震性能を評価す る方法である。建物に設置した加速度センサーによって 得られる地震時の加速度から変位を推定し, 図-1に示

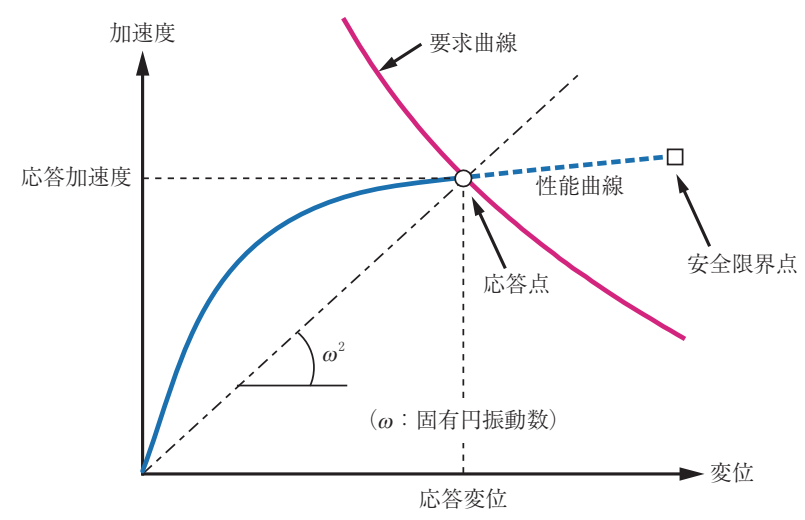

図-1 性能曲線と要求曲線 
すような建物の性能を代表する加速度と変位の関係（性 能曲線）を求める。さらに, 地表面の加速度（主として 1 階の加速度を利用) から要求曲線を求め, 性能曲線と 要求曲線の交点である建物の応答点（図-1 中○印）を 推定し, 応答時の加速度や変位の推定を行うことが可能 である。性能曲線の推定により, 地震前後の建物の剛性 変化や最大応答変位の推定が可能となる。また, 原点と 応答点を結んだ直線の傾きが応答時固有円振動数 $\omega$ の 2 乗 $\left(\omega^{2}=(2 \pi / T)^{2}, \quad T\right.$ : 固有周期 $)$ を表す。性能曲線の 応答点より先の破線は推定される性能曲線であり, 建物 の許容できる加速度と応答（安全限界点）が分かれば, 建物の残余耐震性能（応答点と安全限界点との差）を評 価することができる。

性能曲線は建物を 1 質点系に縮約することで求まる代 表加速度と代表変位から算出する。代表加速度には, 建 物の各層に加速度センサーを設置した場合に扔いて，各 層の加速度の時刻歷から, ウェーブレット変換を用いて 抽出した 1 次モード成分の加速度を用いる4)。加速度の 2 階積分により变位を求めたのち, 多質点系の基礎に対

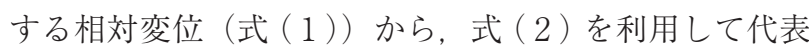
加速度 ${ }_{1} \ddot{\Delta}+{ }_{1} \ddot{x}_{0}$ を算出する。代表変位は, 各層の質量（ま たは質量比）と加速度の 1 次モード成分から式（3）に より算出する。図-1 のように縦軸に代表加速度を, 横軸 に代表変位をとることで性能曲線を求めることができる。

建物のベースシアーは縦軸の加速度に等価質量 ${ }_{s} \bar{M}$ (式 （4））を乗ずることで求まり, 耐力と剛性を直接的に推 定することができる。地震時に打いては，規模に依存す るものの, これらの推定を早ければ数秒間でリアルタイ ムに行うことが可能であり，本震で被害を受けた建物の 性能変化を把握し, 余震やその後の地震に対する建物性 能を瞬時に推定する。この方法により，被災後の避難や 継続使用㧍よび補強などの判断の手助けとなりうる。さ らに, 複数の地震動時の応答を継続して記録することで, 建物の劣化や保有性能の経時変化, 残余耐震性能の把握
も可能になる。

$$
\begin{aligned}
& { }_{1} x_{i}=\iint\left({ }_{1} x_{i}+{ }_{1} \ddot{x}_{i}\right) d t^{2}-\iint{ }_{1} \ddot{x}_{0} d t^{2} \\
& \left.{ }_{1} \ddot{\Delta}+{ }_{1} \ddot{x}_{0}\right)=\frac{\sum m_{i} \cdot{ }_{1} x_{i}^{2}}{\left(\sum m_{i} \cdot{ }_{1} x_{i}\right)^{2}} \cdot \sum_{i=1}^{N} m_{i} \cdot \ddot{x}_{i}+{ }_{1} \ddot{x}_{0} \\
& { }_{i} \Delta=\frac{\sum m_{i} \cdot{ }_{1} x_{i}^{2}}{\sum m_{i} \cdot{ }_{1} x_{i}} \\
& { }_{s} \bar{M}=\frac{\left(\sum m_{i} \cdot{ }_{1} x_{i}\right)^{2}}{\sum m_{i} \cdot{ }_{1} x_{i}^{2}}
\end{aligned}
$$

ここで， ${ }_{1} x_{i}$ ：基礎に対する相対変位， $\ddot{x}_{i}: 1$ 次モード 相対加速度成分, ${ }_{1} \ddot{\Delta}: 1$ 次の代表加速度の建物応答成分, ${ }_{1} \ddot{x}_{0}$ : 地動加速度の 1 次モード固有振動成分, $m_{i}$ : 各層の 質量

\section{3. 即時耐震性能評価システムの概要}

即時耐震性能評価法は前述のと㧍り, 加速度の計測に よって実現するものであり, 性能の評価は加速度センサー の性能（精度と感度）に依存する。本法では主に中地震 から大地震時を想定しており, 比較的感度がよく, かつ， リアルタイムで加速度が計測できる加速度センサーが望 ましい。また，本システムの精度の向上を図るには建物 の各層に設置するのが望ましいことから，機器間におけ る高精度の時刻同期性能が求められる。複数台の設置や 普及を考慮すると, より安価であることも重要である。

以上の理由から, 本法の加速度センサーには東京大学 地震研究所で開発されたIT 強震計) を使用している。 IT 強震計の外観を写真-1 に示す。IT 強震計の外形寸法 は幅 $100 \mathrm{~mm}$, 奥行き $170 \mathrm{~mm}$, 高さ $41 \mathrm{~mm}$ である。本 体には運転状態を表すインジケータが搭載されており, 外部接続端子として電源入力端子とイーサネット接続端 子抢よび SD カード挿入スロットを有する。IT 強震計 の性能を表-1に示す。IT 強震計は付属のソフトウェア により, 微動から強震動までを継続して, 24 時間 365

\section{Demonstration Experiment of Instantaneous Seismic Capacity Evaluation Method Using Accelerometers at University Research Building \\ By Y. Hibino, K. Kusunoki, M. Teshigawara and M. Araki \\ Concrete Journal, Vol.54, No.3, pp.268 274, Mar. 2016}

Synopsis Health monitoring technology has been attracting attention in recent years as a method to evaluate the seismic performance of buildings. This paper introduces a demonstration experiment of an instantaneous seismic capacity evaluation method using accelerometers carried out on a steel reinforced concrete building of the Faculty of Engineering at Hiroshima University. The proposed seismic performance evaluation method was verified by calculating the capacity curve of the building based on the acceleration history of a building during earthquakes as measured by accelerometers, and comparing it with the demand curve obtained from the foundation input acceleration and acceleration records obtained at nearby strong motion observation points. The validity of this evaluation method was demonstrated through comparison of the natural period obtained from the transfer function and the skeleton curve of the capacity curve, and the relationship diagram of the capacity curve and demand curve.

Keywords : accelerometer, instantaneous seismic capacity evaluation, capacity curve, demand curve, natural period, transfer function 


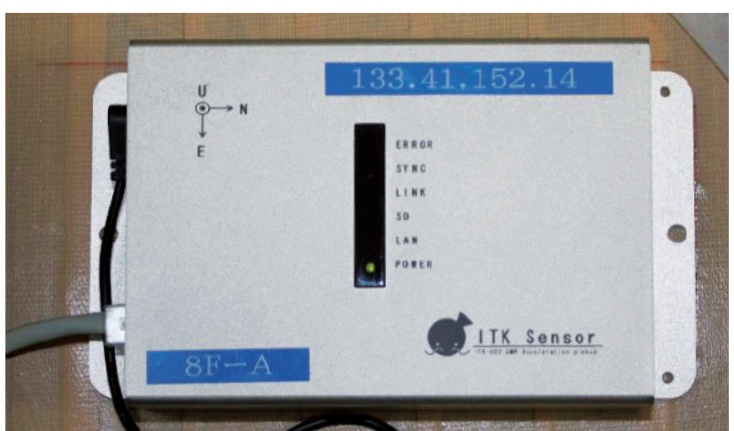

写真-1 IT 強震計の外観

表-1ＩT 強震計の性能

\begin{tabular}{|c|c|}
\hline 計測デバイス & GMR 加速度ピックアップ \\
\hline 計測加速度軸 & X, Y, Z (3 軸) \\
\hline 定格加速度レンジ & $\pm 2450 \mathrm{Gal}$ (X, Y, Z 軸) \\
\hline ノイズ & $0.1 \mathrm{Gal}$ 未満 \\
\hline 定格電圧 & DC $6 \mathrm{~V} \pm 10 \%$ \\
\hline 取り付け許容角度 & 水平取り付け $\pm 3^{\circ}$ 以内 \\
\hline 時間精度 & NTP に依存 \\
\hline
\end{tabular}

$4 \mathrm{~F}-\mathrm{C}$

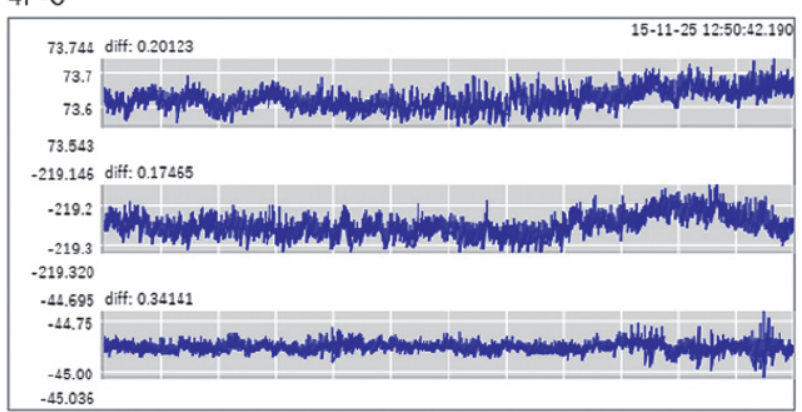

$\triangle+-$

$8 \mathrm{~F}-\mathrm{B}$

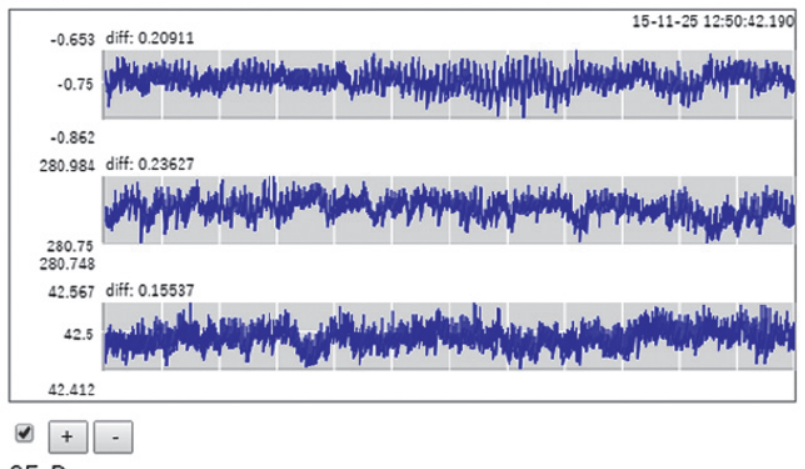

$8 \mathrm{~F}-\mathrm{D}$

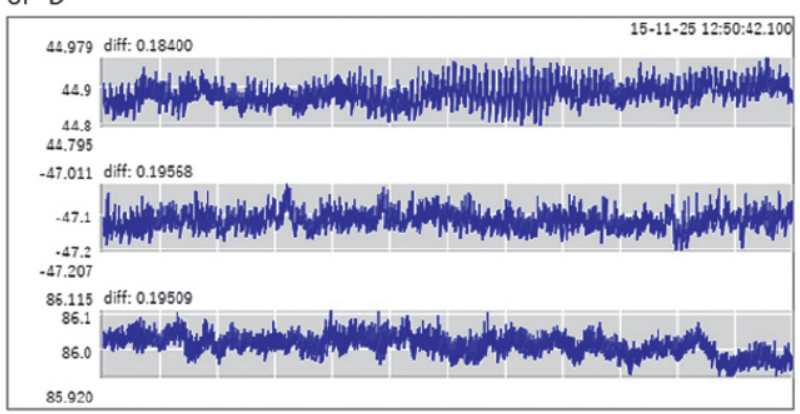

$\nabla+-$
日リアルタイムで計測が可能である。IT 強震計はサー バーと接続され，収集した加速度がリアルタイムでサー バーに集積される。イーサネットを通してサーバーのコ ンピュータと接続される。時刻同期はNTP (Network
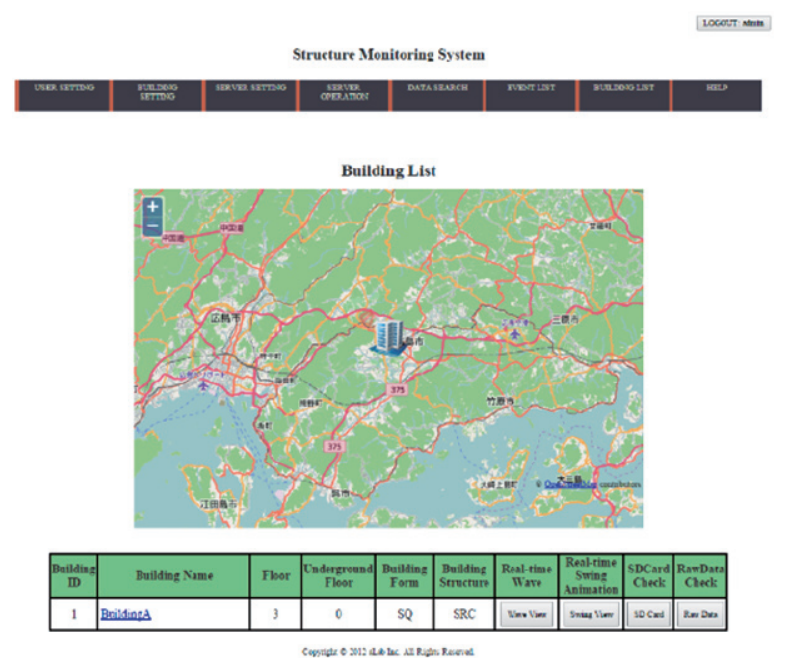

図-2 サーバーの Web ページ

$8 \mathrm{~F}-\mathrm{A}$

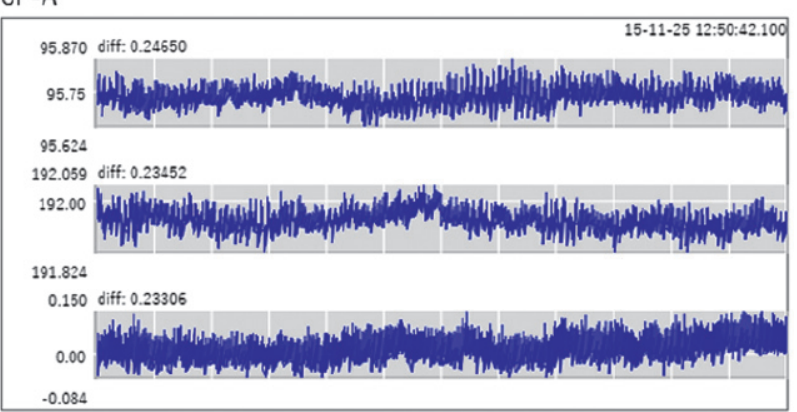
$\rightarrow+-$

$8 \mathrm{~F}-\mathrm{C}$

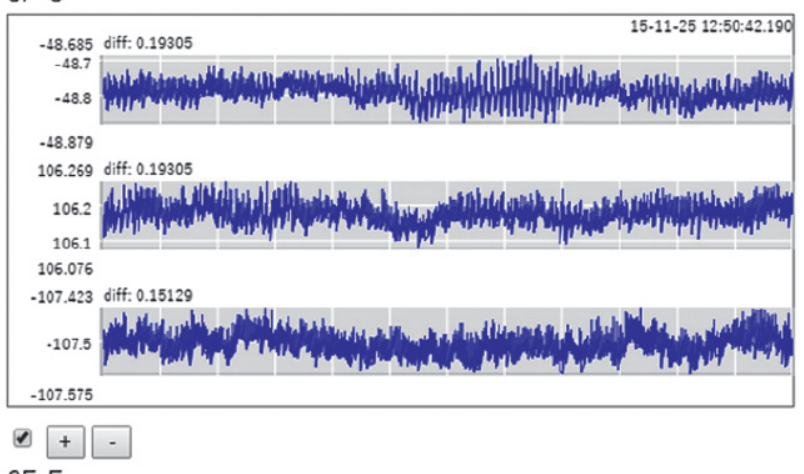

$8 \mathrm{~F}-\mathrm{E}$

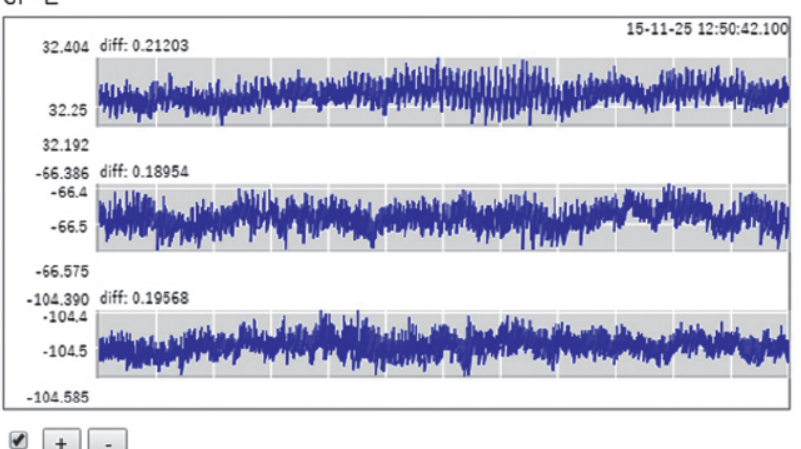

図-3リアルタイム波形表示 
Time Protocol）を利用して行う。収集された加速度デー 夕はサーバー内に蓄積される。ただし，停電時においては， サーバーや加速度センサーの電源䘫失によりデー夕の送 信はできない。イーサネットの衰失時においては，加速 度データは一時的に加速度センサー本体に挿入した SD カードに保存され，ネットワーク回復後に自動送信され る。なお，本センサーは現在，イーサネット回線を利用 して電源を供給する技術 (Power on Ethernet：POE) を使用したセンサーを開発中であり，加速度センサーに イーサネットを接続するだけで計測システムの構築が可 能になる。

収集したデータにはサーバー上の Web ページ（図-2） からアクセスし，任意の時刻と時間間隔の加速度波形の表 示とダウンロードができる。さらに，計測しているデータ をリアルタイムに表示させることが可能である（図-3）。 強震時（任意のトリガーが設定可能）においては，自動 でイベントを作成し，強震動のイベントのリストを蓄積 する。また，前述のとおり，加速度デー夕は常に収集さ れているため，イベントが作成されなかった場合におい ては，任意の時刻でのイベント作成が可能である。

\section{4. 広島大学工学部棟での実証実験}

\section{1 加速度センサーの設置}

即時耐震性能評価法の実証実験は, これまで多くの建 物で行われてきている例えば7)。本稿では筆者の所属する広 島大学工学部の研究棟である A 2 棟での実証実験の内容 について示す。広島大学工学部は広島大学東広島キャンパ スの東端に位置している。広島大学工学部 A 2 棟の位置お よび，設置建物から最も近い強震観測点である K-NET 東広島の位置8) を図-4に示す。K-NET 東広島は広島大 学から北東に約 $4 \mathrm{~km}$ 離れた地点に設置されている。

広島大学工学部 A 2 棟ではこれまでに加速度センサー

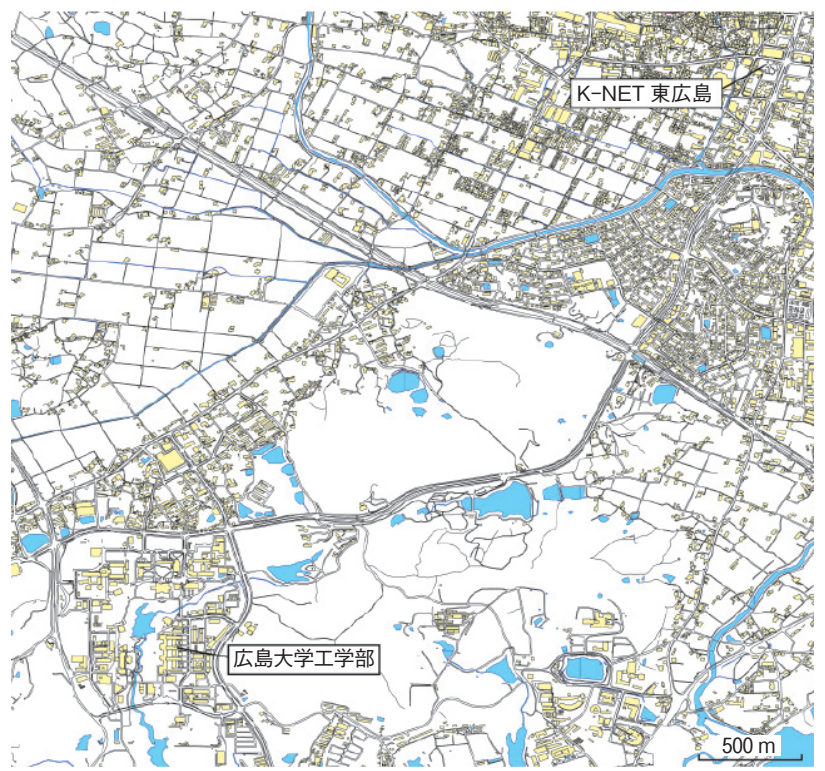

図-4 広島大学工学部 A 2 棟と K-NET 東広島
(現在は撤去済み $)^{9)}$ や地震計の設置 ${ }^{10)}$ が行われてきてい る。本建物は鉄骨鉄筋コンクリート造の地上 9 階（PH 階含む）建てで地下 1 階を有する建物である。建物の外 観を写真-2に，諸元を表-2に示す。また，図-5に8階 の平面図を，図-6にX 1 通りの軸組図を示す。本建物 は 1981 年に施工され，2010 年に耐震補強工事が行われ ている。南北が梁間方向であり，9構面中 4 構面に連層 耐震壁を有しており，耐震補強により 1 階から 5 階の耐 震壁が増打ち補強されている。

加速度センサーは 1 階に 2 台，4階に 1 台，8階に 5 台の計 8 台を設置した。加速度センサーは図-5, 図-6 に示すように，主に建物の重心位置付近にある EPS 内 に，1階と 8 階に各 2 台を，4階に 1 台を設置している。 さらに，建物のねじれや偏心応答の計測を行うため，8 階にのみ建物の隅角部付近に 3 台を設置している。表-3 に加速度センサーの記号と設置位置を示す。表中の記号 は図-5 および図-6 と対応している。C 点は建物の重心 位置に最も近い位置に設置されている。1階の重心位置 にある加速度センサー（1 C） は基礎に入力される加速 度の計測に用いる。さらに今後は周辺地盤の加速度を計 測するため, 追加の加速度センサーを周辺の地盤内に設

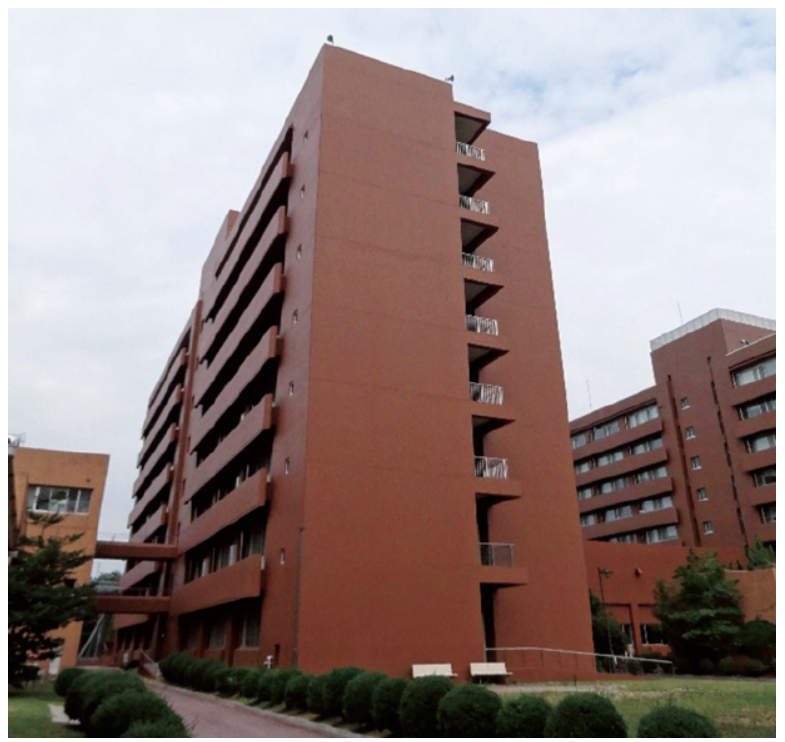

写真-2 広島大学工学部 A 2 棟外観

表-2 広島大学工学部 A 2 棟の諸元

\begin{tabular}{c|c}
\hline 構 $\quad$ 造 & 鉄骨鉄筋コンクリート造 \\
\hline 階 数 & 地上 9 階 $(\mathrm{PH}$ 階含む $)$, 地下 1 階 \\
\hline 築 年 数 & 築 34 年 $(1981$ 年施工, 2010 年耐震補強 $)$ \\
\hline 高 さ & $34.2 \mathrm{~m}(\mathrm{PH}$ 含む $)$ \\
\hline 建築面積 & $997 \mathrm{~m}^{2}$ \\
\hline 延床面積 & $8629 \mathrm{~m}^{2}$ \\
\hline 杭 & $600 \phi($ 場所打ちコンクリート杭 $)$ \\
\hline $\begin{array}{c}\text { コンクリート強度 } \\
\text { (設計基準強度) }\end{array}$ & $21 \mathrm{MPa}$ (地下階〜2 階), \\
\hline $\begin{array}{c}\text { コンクリート強度 } \\
\text { (耐震診断時) }\end{array}$ & $24 \mathrm{MPa}(3$ 階〜屋上階) \\
\hline
\end{tabular}




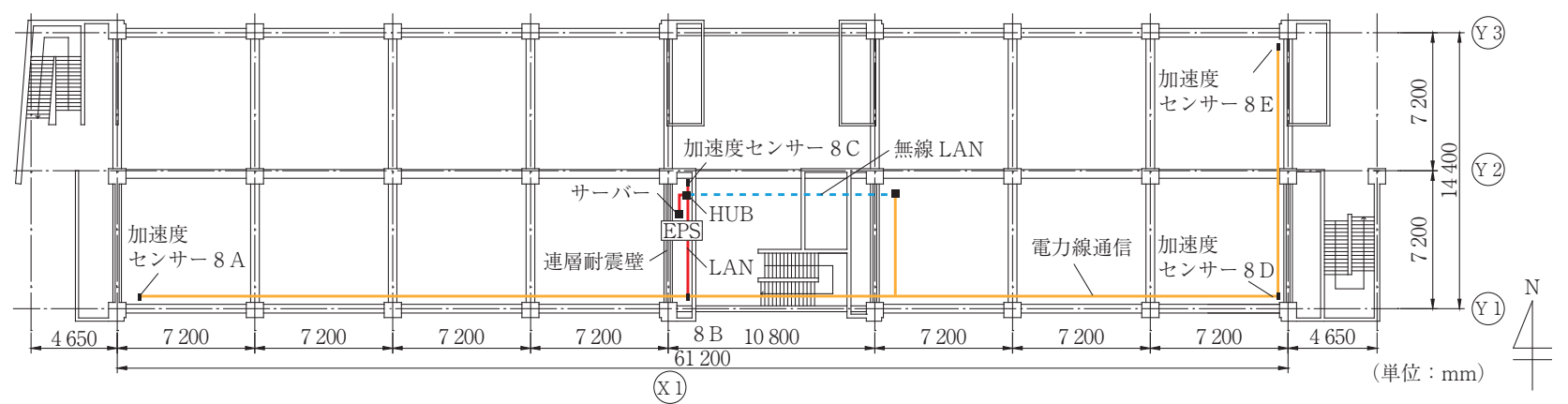

図-5 広島大学工学部 A 2 棟 8 階平面図

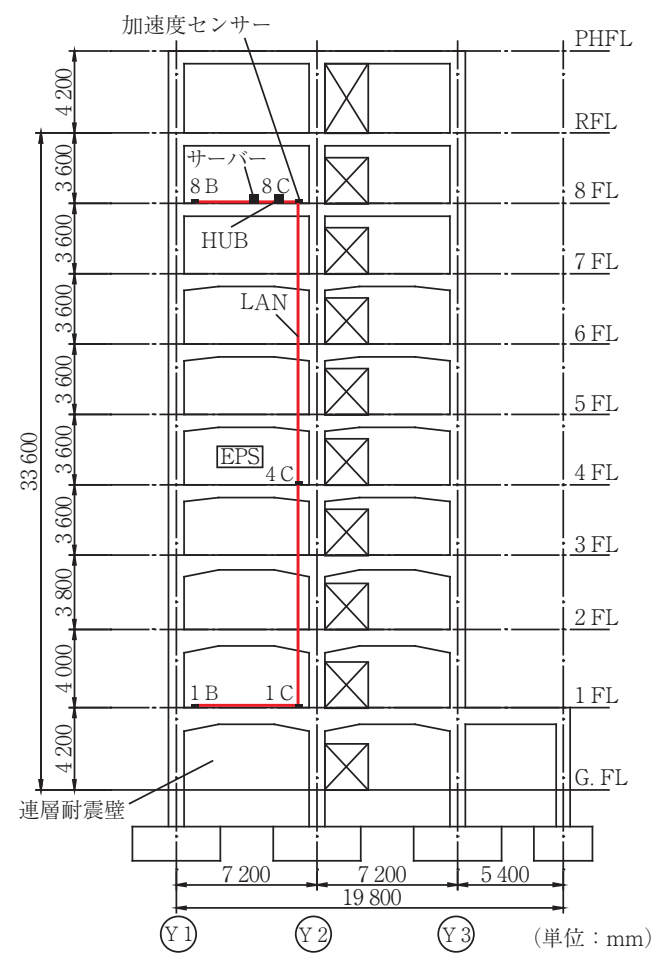

図-6 広島大学工学部 A 2 棟 X1 通り断面図

表-3 加速度センサーの設置箇所

\begin{tabular}{|c|c|c|}
\hline 記 号 & 設置階 & 設置位置 \\
\hline $1 \mathrm{~B}$ & \multirow{2}{*}{1 階 } & $\mathrm{B}$ \\
\hline $1 \mathrm{C}$ & & C (重心位置) \\
\hline $4 \mathrm{C}$ & 4 階 & C (重心位置) \\
\hline $8 \mathrm{~A}$ & \multirow{5}{*}{8 階 } & $\mathrm{A}$ \\
\hline $8 \mathrm{~B}$ & & $\mathrm{~B}$ \\
\hline $8 \mathrm{C}$ & & C (重心位置) \\
\hline $8 \mathrm{D}$ & & $\mathrm{D}$ \\
\hline $8 \mathrm{E}$ & & $\mathrm{E}$ \\
\hline
\end{tabular}

置することも計画している。

加速度センサーは前述のと抢り，イーサネットでサー バーと接続する必要があり, 双方の通信を確保する必要 がある。広島大学工学部 A 2 棟内の各居室にはネット ワークが整備されているが，ネットワークはゾーンで分 かれており，各ゾーンを横断して相互に通信することは 出来ない。そのため, 加速度センサーは設置箇所近くに あるイーサネットに接続しても，そのままサーバーと通 表-4＼cjkstart計測された地震記録

\begin{tabular}{c|c|c|c|c|c}
\hline 記号 & 発生日時 & 震央地名 & $\begin{array}{c}\text { 深さ } \\
(\mathrm{km})\end{array}$ & $\begin{array}{c}\text { マグニ } \\
\text { チュード }\end{array}$ & $\begin{array}{c}\text { 震度 } \\
(\mathrm{K}-\mathrm{NET} \text { 東広島) }\end{array}$ \\
\hline E 1 & $2015 / 7 / 13 / 02: 52$ & 大分県南部 & 58 & 5.7 & 1.8 \\
\hline E 2 & $2015 / 7 / 24 / 17: 54$ & 愛媛県南予 & 44 & 4.6 & 0.7 \\
\hline E 3 & $2015 / 8 / 21 / 16: 55$ & 豊後水道 & 48 & 4.3 & 0.5 \\
\hline E 4 & $2015 / 8 / 26 / 07: 52$ & 日向灘 & 34 & 5.2 & 記録なし \\
\hline
\end{tabular}

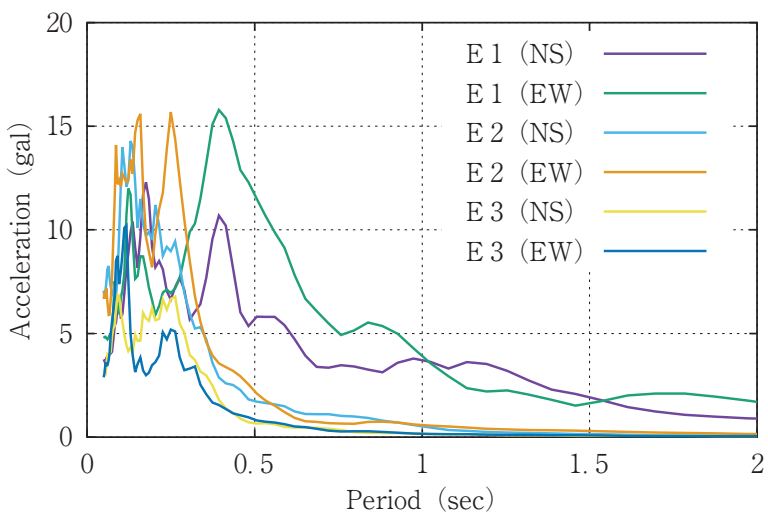

図-7 加速度応答スペクトル

信することは難しい。そこで，本実証実験では，電力線 通信（PLC：Power Line Communication）と無線 LAN によって通信の確保を行った。図-5 および図-6 中の黄色 線が電力線通信, 青破線が無線 LAN, 赤線が有線 LAN による通信を表している。各通信線は EPS 内の HUB を 通して，学内のネットワーク抢よびサーバーと接続した。 8 階以外の加速度センサーは EPS 内で同一ゾーンのネッ トワークに接続し、サーバーとの通信を確保した。

加速度センサーの設置は，コンクリートスラブ上に貼 付した強力な自己融着テープを使用して固定した。

\section{2 計測 記 録}

加速度センサーは平成 25 年 7 月 4 日に設置を行い，本 稿の執筆現在までに計 4 波の加速度記録を収集している。 表-4にこれまでに計測した加速度記録と地震の詳細（発 生日時, 震央地名, 深さ, マグニチュード, K-NET 東 広島で観測された震度）を示す。K-NET 東広島では九 州地方あるいは四国地方での地震によって震度 1 前後が 観測されている。K-NET 東広島で計測された地震波の 減衰定数 $5 \%$ 時の加速度応答スペクトルを図-7に示す。 


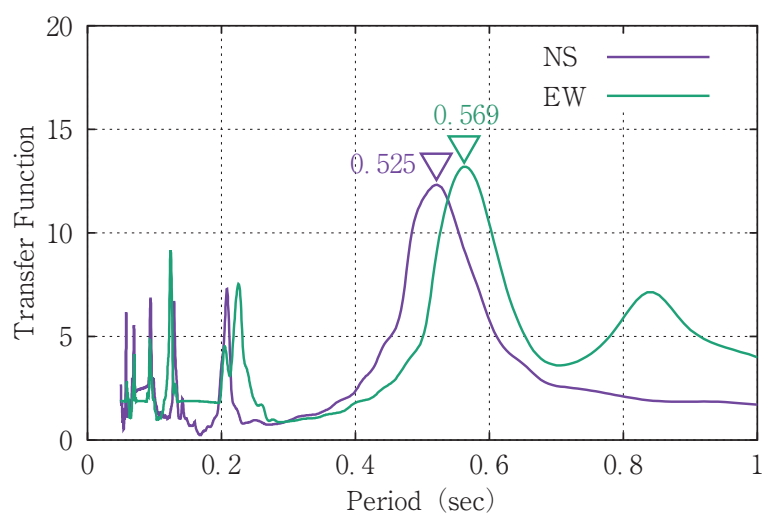

(a) $\mathrm{E} 1$ 地震波

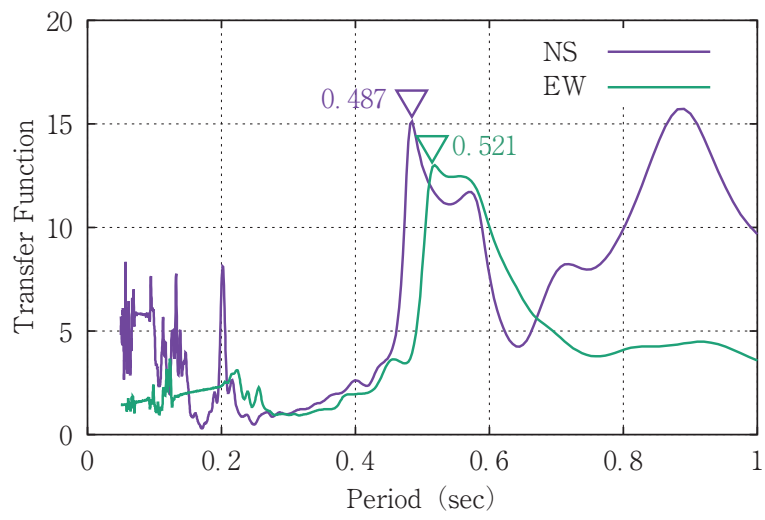

(c) E 3 地震波

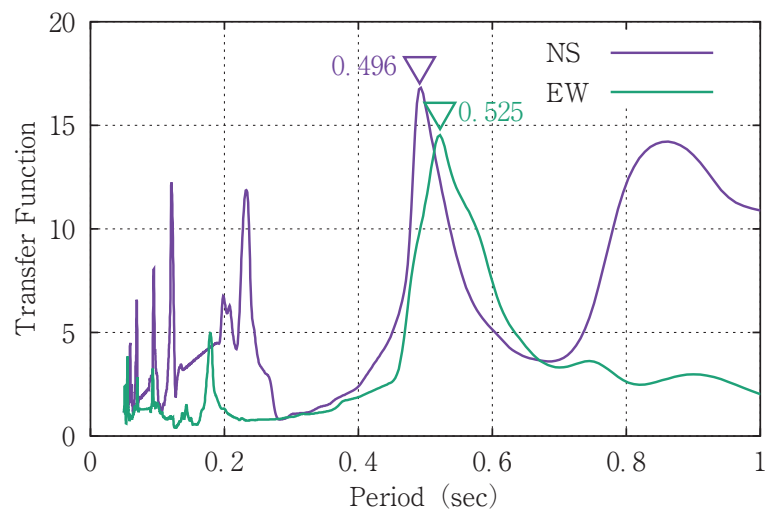

（b） E 2 地震波

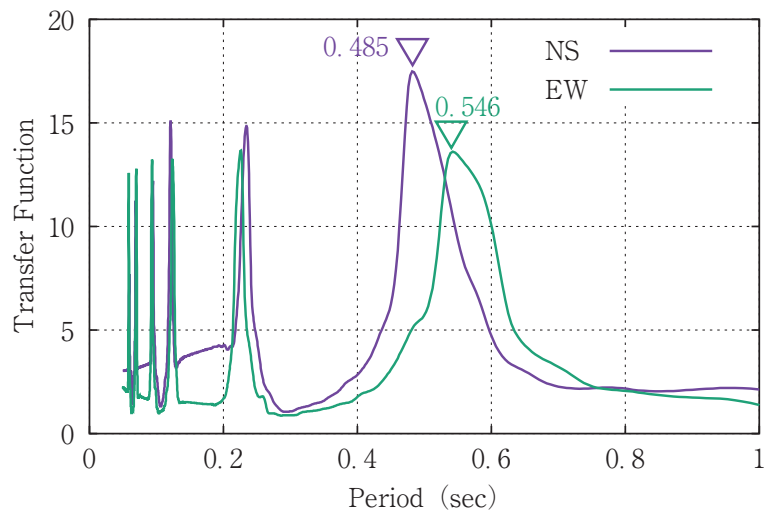

(d) E 4 地震波

図-8 伝 達関数

表-5 ナイキスト周期（sec）

\begin{tabular}{c|c|c|c|c|c|c|c|c}
\hline 時間刻み & ランク 1 & ランク 2 & ランク 3 & ランク 4 & ランク 5 & ランク 6 & ランク 7 & ランク 8 \\
\hline$\Delta 0.01$ & 0.02 & 0.04 & 0.08 & 0.16 & 0.32 & 0.64 & 1.28 & 2.56 \\
\hline
\end{tabular}

なお，E４の地震波については K-NET 東広島において 記録されていない。

\section{3 伝 達関 数}

表-4に示した地震で計測した 1 階と 8 階の重心位置 （1 C， 8C）の加速度記録のフーリエスペクトルにより， 伝達関数を求めた。フーリエスペクトルは $0.2 \mathrm{~Hz}$ の Parzen ウィンドウを用いて平滑化を行った。伝達関数 は 8 階のフーリエスペクトルを 1 階のフーリエスペクト ルで除して求めた。図-8に各地震記録の伝達関数と卓 越周期を示す。 1 次固有周期はピーク值より NS 方向は $0.48 \sim 0.53$ 秒， $\mathrm{EW}$ 方向は $0.52 \sim 0.57$ 秒と算出された。 $\mathrm{NS}$ 方向は連層耐震壁を有するため, NS 方向の固有周期 は $\mathrm{EW}$ 方向よりも小さくなったと考えられる。なお，耐 震補強前の 1 次固有周期は既往の文献 9）よりいずれの 方向においても 0.5 秒程度であると示されており，伝達 関数より求めた 1 次固有周期とほぼ同じであった。耐震 壁の増打ち補強などの耐震補強により剛性が高くなって いると考えられるが，1 次固有周期からはその効果を確 認できなかった。なお，建物高さより略算した 1 次固有 周期は $T=0.02 \times 33.6=0.672$ 秒となり算出結果よりも 若干長いが，おおよそ近い值となった。

\section{4 性能曲線と要求曲線}

$\mathrm{E} 1$ 地震波について, 本建物の性能曲線の推定と要求曲 線を用いた耐震性能評価を試みた。性能曲線は 2 章で示 したように，代表加速度と代表変位から算出を行う。そ の際には 1 次モード成分の加速度を抽出する必要がある ため，ウェーブレット変換による方法を用いる。建物の 1 次固有周期と表-5 に示す時間間隔 0.01 秒時のナイキスト 周期を元に適切なランクの成分を抽出する必要があるが, 本建物の 1 次固有周期が約 0.5 秒であることから, 本稿 ではランク 5 とランク 6 の成分を用いた。使用した加速度 記録は 1 階，4 階，8階の重心位置に設置された加速度セ ンサー（1C，4C，8C）を用いて，式（2）および式（3） により算出を行った。なお，本建物では，加速度センサー の位置が各層ではないため，簡易的に 3 層の建物として 計算を行う。また，各層の質量は等しいと仮定した。図-9 にE 1 地震波における NS 方向および $\mathrm{EW}$ 方向の性能曲 線と要求曲線を示す。要求曲線は 1 階重心位置の加速度 (1 C) と K-NET 東広島の加速度の減衰定数 $5 \%$ 時の応 答スペクトルから求めている。また, 性能曲線から求めた 骨格曲線の最大変位時の傾きから固有周期を算出した。

$\mathrm{NS}$ 方向の性能曲線はいずれの要求曲線とも交差しな 


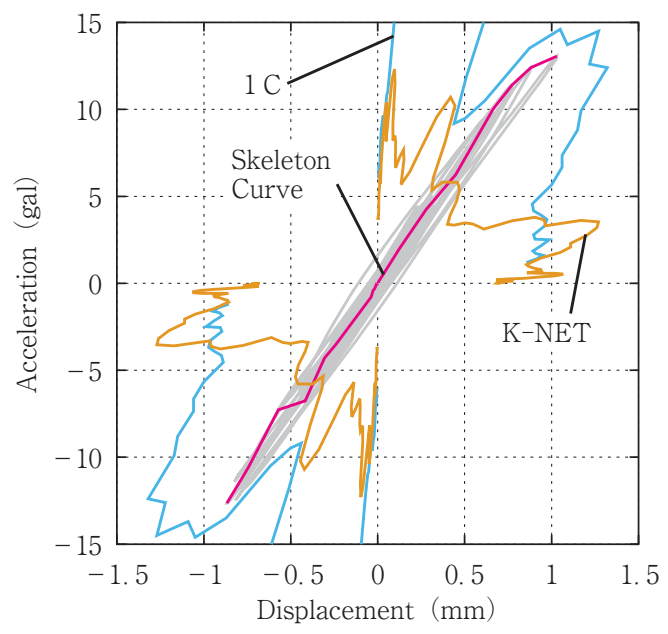

(a) NS 方向

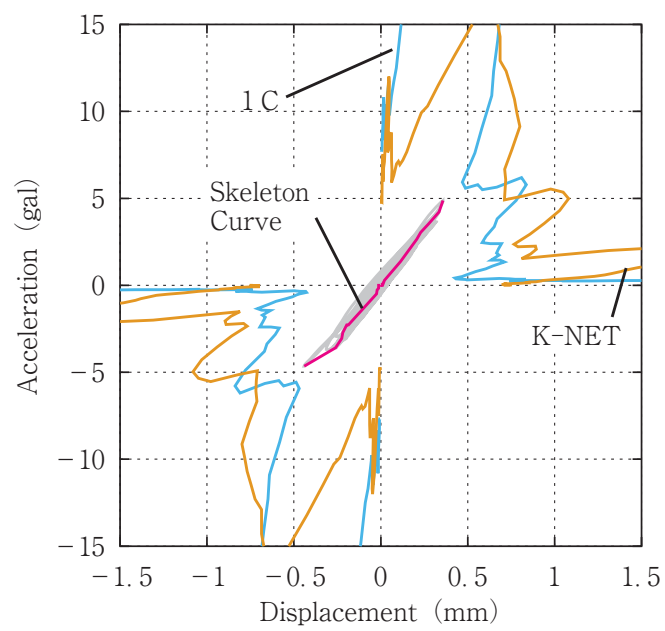

(b) EW 方向

図-9 性能曲線と要求曲線（E 1 地震波）

かったが，1階の重心位置の加速度（1C）と近い值を示 しており，お扔むね適切な性能曲線となっていると考えら れる。ただし，K-NET 東広島による要求曲線は 1 階重 心位置のものよりも著しく小さかった。これは K-NET 東広島との距離や地盤の違いによって生じたものと思わ れる。EW 方向についても 1 階重心位置および K-NET 東広島とも抒抢よそ一致していた。さらに，性能曲線の 骨格曲線から求めた固有周期は NS 方向で 0.56 秒， $\mathrm{EW}$ 方向で 0.61 秒であった。この結果は伝達関数から求め た固有周期と近い值を示しており，算出した性能曲線が 妥当であったといえる。な扔, 本稿に扔いて, 要求曲線 は 1 階の重心位置の加速度を基礎の入力とみなしたが, 基礎の入力加速度が推定できれば，応答点をより精度よ く算出することが可能であると考えられる。また，図-9 の縦軸の加速度に式 (4) で示した等価質量を乗ずるこ とでベースシアーの算出が可能である。

今後の検討課題として, さらなる精度向上が必要であ り，本稿で示したような実在の建物での実証実験や振動 台実験などを通した計算の最適化や精度向上のための技 術の開発が望まれる。

\section{5. まと め}

本稿では構造物のヘルスモニタリング技術の一つとし て加速度センサーを用いた即時耐震性能評価法につい て，広島大学工学部の鉄骨鉄筋コンクリート造建物での 実証実験の概要とその結果を示した。以下に得られた知 見を示す。

（1）加速度センサーを建物内に設置し，学内のネット ワークを利用し，即時耐震性能評価法のシステムを 構築した。

（2）加速度センサーで得られた地震時の加速度記録か ら建物の性能曲線と要求曲線を算出し，建物の耐震 性能評価を行った。

（3）伝達関数，性能曲線から固有周期の推定を行った
結果，NS 方向で $0.48 \sim 0.56$ 秒， EW 方向で 0.52 〜 0.61 秒となり両者とも扮抄よそ近い值を示した。こ のことから，加速度センサーを使用した性能曲線が お打むね妥当なものであったと確認した。

謝＼cjkstart辞＼cjkstart本稿で設置した加速度センサーの購入やシス テムの構築は, (公社) セコム科学技術振興財団による研 究助成「安全・安心のためのリアルタイム残余耐震性能 判定装置の実用化と社会実装」(代表：楠浩一）によっ て実施された。ここに記して謝意を表する。

\section{参 考 文 献}

1）白石理人 ·森井雄史 ·三田 彰：人為的損傷を与えた 5 層 $\mathrm{RC}$ 造 建物の起振機試験による局所損傷検出手法の検証, 日本建築学会 構造系論文集，Vol.80，No.711，pp.745～755，2015. 6

2) 汐満将史・境 有紀：建物に取り付けた単一加速度センサーから 大地震時の建物損傷度を判定する方法に関する研究，(その3）実 大木造建物振動実験デー夕を用いた地震前後の周期の伸びによる 最大変形角の推定, 日本建築学会大会学術講演梗概集 B-2, 構造 II, pp.1017 1018, 2010. 7

3）川村 学・楠 浩一・山下美帆・服部勇樹・日向大樹・ディアス ミゲール・田才 晃：加速度計を用いた実構造物の性能曲線算出 法に関する研究，1質点系構造物の場合，日本建築学会構造系論 文集，Vol.78，No.688，pp.1061 1069，2013.8

4）楠 浩一 ·日向大樹 ·服部勇樹 ·田才 晃：加速度計を用いた実 構造物の性能曲線算出法に関する研究, 多質点系構造物の場合, 日本建築学会構造系論文集，Vol.79，No.699，pp.613～620，2014.7

5) Freeman $\mathrm{SA}$ : Review of the development of the capacity spect rum method, ISET Journal of Earthquake Technology, Paper No.438, Vol.41, No.1, pp.1-13, 2004. 3

6）鹰野 澄・伊藤貴盛・原 徹夫：IT 強震計一その概念と試作一 日本地震学会大会予稿集 2004 年度秋季大会, No.P001, 2004. 10

7）楠 浩一・日向大樹・服部勇樹・古川直矢・田才 晃：リアルタ イム残余耐震性能判定装置の開発，その 26 鉄骨 18 層建物を用い た振動台実験への適用，日本建築学会大会学術講演梗概集 2014 , 構造 II, pp.79 80, 2014. 9

8）国土交通省国土地理院：基盤地図情報ダウンロードサービス http:/ fgd.gsi.go.jp/download/

9）片谷陽子 - 児玉智彦 - 椛山健二・荒木秀夫 ·菅野俊介：2001 年芸 予地震における広島大学工学部研究棟の地震観測および弾塑性解 析，日本建築学会技術報告集，No.15，pp.367～370，2002. 6

10）三浦弘之・真鍋良輔・神野達夫：地震観測および微動観測に基つ く造成地に掞ける地盤特性の評価, 日本建築学会学術講演梗概集 2013, 構造 II, pp.221 222, 2013. 8 